This item was submitted to Loughborough's Research Repository by the author.

Items in Figshare are protected by copyright, with all rights reserved, unless otherwise indicated.

\title{
Introduction: Global Modernism
}

PLEASE CITE THE PUBLISHED VERSION

https://doi.org/10.3366/mod.2018.0191

PUBLISHER

(c) Edinburgh University Press

VERSION

AM (Accepted Manuscript)

PUBLISHER STATEMENT

This work is made available according to the conditions of the Creative Commons Attribution-NonCommercialNoDerivatives 4.0 International (CC BY-NC-ND 4.0) licence. Full details of this licence are available at: https://creativecommons.org/licenses/by-nc-nd/4.0/

\section{LICENCE}

CC BY-NC-ND 4.0

\section{REPOSITORY RECORD}

Jaillant, Lise, and Alison E. Martin. 2019. "Introduction: Global Modernism”. figshare. https://hdl.handle.net/2134/28288. 


\section{Introduction}

\section{Lise Jaillant and Alison E. Martin}

In March 1913, Ezra Pound wrote an article on the Bengali poet Rabindranath Tagore for the Fortnightly Review. ${ }^{1}$ Pound had just heard Tagore read his translated poems at a party in London, and displaying typical energy, he was on a mission to share his discovery with the world. But the article - with its repetitions of 'great poet', 'great musician' and 'great artist' - did not appeal to everyone. The Times of India declared: 'it is an effusive and badly constructed criticism but has some value as showing the extent to which the devotion to this Bengali poet has gone in England' ${ }^{2}$ Transnational literary relationships in the early twentieth century worked in multiple ways. Tagore influenced Anglophone writers in London (including the American expatriate Pound), and back in India, his reputation increased thanks to his new reputation in the imperial capital. These literary ties shaped the nature of modernism as a truly international movement, and yet, for a very long time, scholars focused on the London - Paris - New York axis and neglected exchanges that did not fit in this model.

This changed in the early 2000s, with a new wave of scholarship on the modernists' engagement with imperialism, colonialism and globalisation. 'There can be no doubt that modernist studies is undergoing a transnational turn', wrote Douglas Mao and Rebecca Walkowitz in their influential 2008 article in PMLA. ${ }^{3}$ This transnational turn, combined with the 'rise of periodical studies' described by Sean Latham and Robert Scholes, has led to a growing scholarship on the networks that allowed modernist texts to circulate in Britain, America and elsewhere. For example, the Modernist Journals Project website includes electronic copies of magazines published on both sides of the Atlantic, for small or larger audiences. In the UK, the Modernist Magazines Project, directed by Peter Brooker and Andrew Thacker, has led to the publication of a history of these magazines in Britain and Ireland (Vol. 1), North America (Vol. 2) and Europe (Vol. 3). In 2012, Modernism/ Modernity also published a special issue on 'Print Culture and Transatlantic/ 
Transnational Public Sphere(s)', with a particular focus on 'the Atlantic scene of English-language publication'. ${ }^{4}$ In her introduction, the editor Ann Ardis wrote about 'the methodological convergences of periodical studies, book history, media history, and material culture studies that are enriching our understanding of modernism's complex relationship to the media ecology of modernity, ${ }^{5}$ In their preface to the 2016 edited volume Moving Modernisms: Motion, Technology, and Modernity, Laura Marcus and David Bradshaw remind us, issues of 'locality and regionalism, internationalism and transnationalism, borders and diaspora, and cosmopolitanism and translation’ now increasingly inform models shaping world literatures and global modernisms. ${ }^{6}$

This special issue focuses on precisely how modernist texts 'travelled' from their original place of production, publication and reception to rather different spaces of consumption, and it explores the conduits established by authors, editors, publishers and translators that enabled these works to circulate. Susan Stanford Friedman has described the 'New Modernist Studies' as characterised by a shift away from understanding modernism 'primarily in formalist terms as a loose affiliation of movements coalescing around certain aesthetic rebellions, styles, and philosophical principles' towards an understanding of the 'specific conditions of modernity'.7 Modernism, she argues, itself opened up a domain of creative expressivity within modernity’s dynamic of rapid change: ${ }^{8}$ the articles collected here explore how, as texts moved beyond the original sphere in which they were created, different agents exploited these expressive possibilities as works entered the 'transit zone'.

Shifts in spatial and geographical location are central to some of the questions that we address here as we explore the new arenas into which works entered and the networks of cultural exchange thus created. As Brooker and Thacker rightly query, 'where was modernism?' They ask us to look beyond the metropolitan centres normally associated with modernism to consider other sites that were equally important, if often downplayed, in the production and circulation of modernist literature. ${ }^{9}$ In line with Arjun Appadurai’s notion of 'modernity at large' (1996), we seek here to investigate the wider spatial distribution of modernist formations and the cross-fertilisation 
of ideas and practices. As scholars increasingly turn their attention to 'modernism's changing forms and configurations in different European and world locations', the transnational as much as the distinctly national character of different facets of literary modernism is also thrown into sharper relief. ${ }^{10}$ As Andreas Huyssen reminds us, 'there can be no purely global culture totally separate from local traditions'. ${ }^{11}$ Gatekeepers enabled foreign literatures, languages and cultures to be integrated into these local traditions, and in turn, these traditions influenced the modernist movement.

Publishers played a major role in the circulation of modernist texts in the metropolitan centres and in the periphery, thus facilitating cultural exchanges and shaping modernism as a truly cosmopolitan movement. And yet, few modernist scholars have paid attention to these transnational publishing networks. Responding to this gap in scholarship, Amy Blair has suggested adding a book history perspective to the study of global modernism. The 'breakdown of national borders will be a crucial element for scholars to consider', Blair writes. 'This will need to extend to non-Anglophone literatures as well; novels in translation by French (Blaise Cendrars), Norwegian (Knut Hamsun), and German (Erich Maria Remarque) authors, among others, were highly influential in the American scene and were read in dialogue with Anglophone moderns'. ${ }^{12}$ Indeed, cultural exchanges worked in multiple ways, and the study of the modernist book trade should not be restricted to the English-speaking sphere. At the beginning of the twentieth century, Anglophone modernism was sold in India, China, Japan, Russia and other countries. And in turn, experimental texts in translation were available in Britain, the United States, Canada, and Australia. For example, Arthur Waley's translations of The Tale of Genji - reviewed by Woolf - appeared in 1925 under the Allen \& Unwin imprint. These exchanges did not happen magically: publishers commissioned translations and opened up new international markets for modernism, thus reaching new audiences. By the mid-1920s, even the Hogarth Press - initially a hobby for Woolf - had become a commercial enterprise with a sophisticated marketing strategy and ability to negotiate rights at the international level. The trade in non-Anglophone literature in translation had a huge impact on Anglophone 
modernists, an aspect that has been studied at the textual level while the specifics of the book trade have been largely neglected.

Susan Stanford Friedman rightly asks how modernist studies can come to think of itself as 'global' and 'planetary' if it is monolingual: that is, if it largely remains within the confines of English and does not seek to understand how texts permeate the boundaries of the Anglophone world. ${ }^{13}$ She draws welcome attention to the fact that translation on a linguistic level 'has a central role to play in the multilingual globalization of modernist studies'. ${ }^{14}$ Precisely because equivalence is near-impossible in the transfer of creative products from one language to another, this makes translators pivotal figures in modernist literary production through their subtle restyling and reorientation of a text, as much as their sometimes quite blatant textual additions and omissions. Friedman's call for the notions of 'revision', 'recovery', 'circulation' and 'collage' to be incorporated into future scholarship has already begun to be taken up by scholars of translation working in the field of modernist studies. ${ }^{15}$ The act of re-vision - of 'looking again' - more generally invites scholars not to take translations at face value but to understand the mediated nature of text in translation. By digging in the archives, we can recover important information about the identities, agendas and motivations of those central - yet often overlooked - middle-men and women who ensured that texts became 'mobile' and travelled across cultural and linguistic boundaries. Enhancing the visibility of these key agents in literary transfer also allows us to understand better the politics of assimilation or alienation which they adopted as they introduced their work into a different culture - strategies of textual ‘migration' which draw important parallels with issues of alterity, dislocation and displacement at the heart of modernist artistic production. ${ }^{16}$

Rebecca Beasley’s essay 'Modernism’s Translations’ is important in highlighting the power that translation embodies to transform texts in a variety of different ways. She emphasises the ability of translation to 'draw attention to cultural difference', 'destabilize universalist idioms and historicize contexts'. ${ }^{17}$ Indeed, she argues, 'aesthetic modernism recognized translation, in theory and in practice, as central to its project'. ${ }^{18}$ In exploring the flow of cultural materials across the 
globe, she highlights the need to analyse translations not only in terms of what happens to the texts themselves as they undergo linguistic transfer, but also the different speeds at which these materials are transmitted and how they are actively transformed by the processes of translation, dissemination and reception. ${ }^{19}$ Attention to the individual fates of different works in translation would help to dispel a 'false sense of homogeneity' that we might otherwise feel about how texts travel between different communities. ${ }^{20}$ In line with the turn away from normative approaches in translation studies to more descriptive investigations of how and by whom texts are rewritten, rethought and repackaged in translation, Beasley encourages modernist scholars to understand translation as 'a means by which nations could represent their identity abroad and receive information about new political allies and antagonists' and to recognise its potential in advancing a particular modernist cultural agenda in a specific context. ${ }^{21}$

The study of global modernism should not be limited to the international circulation of Anglophone texts or to the influence of non-Western texts in translation. In this special issue, Ira Nadel invites us to pay attention to multiple-way cultural exchanges through the example of Bloomsbury and the 'Orient'. Focusing on the literary, artistic and decorative works produced by the Bloomsbury group, Nadel sheds light on the plurality of interactions with a broadly defined Orient ranging from China and Japan to India and Ceylon.

The combined East and West aesthetic led to a so-called 'oriental' style, with highly stylized portraits masking the form of the body. Photographs of Virginia Woolf exemplify this orientalising of image, showing her carefully posed and dressed, with no emphasis on her height and physical form. Vanessa Bell's paintings are often reminiscent of oriental art, with the merging of object and surrounding, and the reduction or elimination of perspective. Duncan Grant, who spent the first ten years of his life in India and Burma, is another Bloomsbury figure influenced by the Orient. In a 1910 portrait, James Strachey, a younger brother of Lytton, sits in a low chair in front of a red screen with oriental figures. Using rapid brushwork, Grant’s Abstract Kinetic Collage Painting with 
Sound (1914-15) parallels a famous Chinese scroll painting: 'Riverside Scene at the Qingming Festival', created in the twelfth century to capture urban life during the Northern Song Dynasty.

The blended Oriental/Bloomsbury aesthetic characterised visual art, but also literature. Nadel outlines three stages of Woolf's knowledge of oriental culture. First, Woolf discovered oriental objects at the British Museum, and read about a romanticized Orient in the works of Marcel Proust and others. Second, Vita Sackville-West's journeys of 1926-1927 with her husband Harold Nicolson inspired Woolf's writings, as Orlando shows. The third stage of Woolf's oriental education occurred in the 1930s, when her nephew Julian Bell travelled to teach in China.

Nadel also examines the influence of Bloomsbury in the East - for example, through the poetry of Xu Zhimo, who studied at Cambridge between 1921 and 1922 with Goldsworthy Lowes Dickinson and George 'Dadie’ Rylands and became a friend of Roger Fry and Bertrand Russell. After returning to China, Xu Zhimo founded the influential Crescent Moon group and embraced the self-expression characteristic of the Bloomsbury group, including the values of open feelings and mutual love. The Chinese writer and painter Lin Shuhua was also close to Bloomsbury. She had a love affair with Julian Bell, was an avid reader of Virginia Woolf and kept a watercolour by Roger Fry in her home. These Chinese artists were not passively influenced by Bloomsbury: they also shaped the group through close relationships and cultural exchanges.

In the next essay, Douglas Mao explores the trajectory of modernist innovation from margins to metropolitan centres, with a particular emphasis on the figure of the Philosopher-Kid in the work of the Barbadian writer George Lamming. Boy Blue, a character in Lamming's autobiographical novel In the Castle of My Skin, resembles other modernist philosopher-children living at the periphery - including Waldo in Olive Schreiner's Story of an African Farm and Darl in William Faulkner's As I Lay Dying. Broadening the focus from literary text to literary institution, Mao gives an overview of Lamming's career trajectory. As a young man, Lamming was influenced by the writer Frank Collymore, who founded and edited Bim magazine, where many Caribbean 
writers placed their work. After moving to London in 1950, Lamming interacted with institutions such as the BBC and British publishing houses.

In particular, the BBC radio programme Caribbean Voices aired some of his poems as well as excerpts from In the Castle of My Skin. The income Lamming received was a life saver at a financially precarious time in his career. The programme also helped him attract the attention of distinguished writers (including the poet Stephen Spender who praised his novel). The BBC therefore allowed Lamming to address a relatively large and influential audience in Britain, and in turn, inspired those who had remained in the Caribbean. The British publisher Michael Joseph also took an interest in Lamming and published the Castle in 1953. Reviews of the novel appeared in major periodicals such as the Sunday Times, which presented it as a colonial Bildungsroman: 'Set in a poor shanty town, [...]it is a story of growing up, beginning with the childhood adventures of the author and his friends - Bob and Trumper and Blue Boy - in a world of destroying heat and of rainstorms and floods that carry whole houses away'. ${ }^{22}$ The novel went on to win the Somerset Maugham Award, two years after Kingsley Amis’s Lucky Jim. Mao argues that modernism was part of the institutional web that carried Lamming's voice from the periphery to the imperial centre. At the time when Lamming started his career, Amis and the Movement were openly rejecting the stylistic experimentations and cosmopolitanism associated with the previous generation of modernist writers. Reacting against Amis, Lamming embraced formally challenging writing and positioned himself as a modernist heir. While Movement writers were deeply hostile to the foreign, Lamming and other Caribbean writers targeted readers who had little taste for this Little Englandism. In its review of the Castle, the Times Literary Supplement compared Lamming to Joyce, and suggested renaming his novel The Portrait of the Artist as a Young Barbadian. ${ }^{23}$ In 1950s London, then, modernism could be used as a tool to reach powerful literary communities, thus opening up opportunities for Lamming and other writers from the periphery.

Daniel Göske’s essay is the first of two contributions to this special issue that work as much with metaphorical issues of 'translation' as with the extremely concrete issues of translation as a 
process of interlingual transfer. While translators have tended to remain 'invisible' figures - even to the point of not being mentioned on the title-page of the very work they translated - the turn in modernist studies towards drawing on archival materials has enabled narratives of these pivotal figures to come to light. Beyond the central question of who was prepared to undertake the extremely demanding task of putting modernist literature into a different language, other issues have been raised about who initiated a translation - whether translators seeking work or publishers aiming to expand their foreign literature profile - and with which foreign market in mind. Other questions about the relative 'quality' of the end-product are potentially interlinked with the translators' habitus and their degree of experience in the translation and publishing industries as much as the time pressure under which they were working. By exploring the networks, alliances and interactions among those who facilitate the circulation and transmission of knowledge, scholars of modernist publishing are now able to offer a finer-grained analysis of where, how and by whom those texts that we consider central to British literary modernism were first published elsewhere in the world. Marketing modernism on the international and, indeed, global level, in the 1920s and 1930s was a complex business, not least because of the different structures in the publishing world of the Americas, Britain and the Continent.

In this essay, Göske approaches this intriguing problem by focusing on the foreign reception of Virginia Woolf's work and, specifically, the contacts between the Hogarth Press and the Leipzig Insel Verlag. While the critical reception of Woolf in the German speaking countries has been discussed in, for example, Mary Ann Caws and Nicola Luckhurst's 2002 edited volume The Reception of Virginia Woolf in Europe, much work remains to be done to understand how literary agents and translators negotiated issues of copyright and ownership and how they shaped her work in German. By drawing on archival material from German sources and from the Archive of British Publishing and Printing at the University of Reading - particularly publishers' correspondence with translators and agents - Göske casts new light on how Mrs. Dalloway, To the Lighthouse and Orlando appeared in early German translations. 
Alison E. Martin similarly explores the processes of transfer and translation in an AngloGerman context. However, her essay focuses more on the medial shifts that a work could undergo in translation and the rather different contexts in which works of British modernism appeared on the German literary market. Her research shows that while canonical figures of Anglophone modernism - notably Woolf, Lawrence and Joyce - were energetically translated and edited for the German market, writers that have tended to be neglected by British literary scholars, were actually just as prominent on the German market. Vita Sackville-West is one such example, famed as Woolf's muse, as a regular broadcaster with the BBC, and as a horticultural journalist and the creator of Sissinghurst's gardens, yet considered peripheral to Bloomsbury modernism. Renewed interest in Sackville-West since 2012, the half-century commemoration of her death, and the publication of recent works of popular scholarship - notably Robert Sackville-West’s The Disinherited (2014) and Matthew Dennison's Behind the Mask: The Life of Vita Sackville-West (2014) - have thrown into sharper relief the complexity of her cultural inheritance and her own achievements as a woman of letters. During her lifetime, some of her key novels were published in French, Spanish and Italian, but it was really in the German-speaking world that she achieved wider recognition, particularly in the years leading up to the Second World War and in the 1950s.

In this essay, Martin concentrates in particular on Sackville-West’s short story, Seducers in Ecuador, which had originally been published as a slim volume with the Hogarth Press in 1924. Its 1929 debut in Germany as 'Verführer in Ecuador' in the journal Die neue Rundschau [The New Review] offers an interesting case study not only of how a work could change in form through translation - here from a free-standing novella to a short story in a literary journal - but also change its context through the new set of juxtapositions and cultural associations it acquired by being absorbed into German periodical culture. While the function of small magazines in promoting new ideas or forms of art has been well researched in the context of British modernist writing, little attention has been paid to the reception of translations of such work in European journals. Yet they often functioned as important promotional conduits and were influential in shaping how authors 
gained footholds in foreign markets. Given that Die neue Rundschau aligned Sackville-West's prose alongside that of Thomas Mann and Hermann Hesse, it explicitly positioned her within a European corpus of avant-garde literary production. It also drew her work into the wider context of debate about the future of European cultural relations in the interwar period.

Claire Battershill’s essay explores the international dimensions of periodical publication by modernist writers through a case study of the British journal New Writing. Founded by John Lehmann in 1936, this periodical in book format was originally published by Bodley Head. The idea for New Writing originated for Lehmann at the 1937 International Congress of Writers. Lehmann drew inspiration from the French weekly periodical Vendredi, whose editor, André Chamson, later published an essay in an early issue. In 1938, it moved to the Hogarth Press, where Lehmann was part-owner, having recently purchased Virginia Woolf's share of the firm. A cheaper version, The Penguin New Writing, gained wide distribution in England, publishing forty issues between 1939 and the end of the series in 1950. Over the fourteen years of its existence in various forms published by a handful of publishers, New Writing supported a diverse range of authors and literary styles. It therefore offers a detailed view of a neglected period of transition in the evolution of modernism.

The critical view of New Writing, brought about by Lehmann's own sour remarks in his autobiography, is that its aesthetic was to some degree antithetical to the Hogarth Press and to the high modernist literary ideals of a previous generation. Battershill’s essay seeks to complicate the notion that New Writing marked a straightforward departure from modernist aesthetic practices by looking at its process of publication and circulation, particularly during its early days. She argues that New Writing quickly brought about a renaissance for the Hogarth Press, introducing many of the 'thirties poets' and the new writers of the time into an established modernist publishing institution. Contributors represented a wide variety of nationalities and literary styles, and included George Orwell, Stephen Spender, Christopher Isherwood, V.S. Pritchett, Mikhael Sholokov and 
Ahmed Ali, among many others. It continued to uphold the Hogarth Press's original commitment to providing a platform for works of merit which other publishers had refused.

Battershill's essay draws on archival materials at the University of Reading to trace the transnational publication history of New Writing. It highlights the importance of publishers' archives in giving us valuable new insights into the processes of discussion and intellectual exchange that underpinned what appeared in modernist periodicals. In addition to its conceptual origins at the International Congress, the periodical itself circulated globally and contributed to transnational dialogues about the relationship between imaginative literature and left-wing political thought toward the end of the interwar period. New Writing's overtly anti-fascist politics and editorial leanings made it one of the primary advocates for documentary literary style as a form of political intervention. New Writing's active engagement with its readership can also be traced thanks to the Hogarth Press Order Books, which show the sales and distribution patterns for this important late modernist periodical.

Lise Jaillant also adopts a book history perspective in her essay on cheap reprint series and copyright in a global context. Like the postcolonial authors who made the journey from local to global recognition, modernist writers such as James Joyce and Virginia Woolf saw their texts move out of the coterie towards the international market. But this transition did not happen magically, and the story of global institutions of modernism has yet to be written. Taking a step in that direction, Jaillant's essay takes the example of reprint series published in the United States, Britain and Continental Europe to show the international expansion of modern literature in the early twentieth century. Her central point is that copyright problems limited the reach of these series and slowed down the international expansion of the new literature. One of the most dynamic markets for modern literature was the Far East, where Anglophone publishers could trade books without restrictions. In Continental Europe, low barriers to access stimulated intense competition and the launch of innovative series such as Albatross Modern Continental Library. Jaillant's article includes numerous anecdotes about the obstacles that publishers faced to market modernism to the world, 
and the rewards that they enjoyed when their books were made available to readers from New York to Shanghai.

In the first section of her article, Jaillant shows that the Modern Library - a cheap series of reprints created in New York in 1917 - was sold not only in the United States, but also in Europe, Australia, South America and Asia. Although the Modern Library specialized in contemporary books, these books were not necessarily copyrighted in the US. Titles published after the International Copyright Act of 1891 had to be printed from type set in the United States or from plates made from such type to qualify for protection. Several post-1891 Modern Library titles (including W. H. Hudson's bestseller Green Mansions) were in the public domain, and yet, the reprint publishers often made voluntary payments to the author and to the original publisher. One reason for this practice was to facilitate access to foreign markets. For example, the Modern Library paid royalties to the publisher Alfred Knopf for Green Mansions, making it easier to sell the book in Canada (a market that Knopf's agents were eager to control). A truly international series, the Modern Library sold a wide range of texts: 'middlebrow' novels but also high modernist texts by James Joyce, Virginia Woolf, Gertrude Stein and others. In the second section of her article, Jaillant takes the examples of two European series: Chatto \& Windus's Phoenix Library and Albatross Modern Continental Library. These series were available in bookshops in Paris and elsewhere, and targeted an audience of expatriates and non-English native speakers eager to read Anglophone texts in the original language. Jaillant concludes by inviting scholars to pay more attention to global institutions of modernism, which transformed the new literature into an internationally-recognisable brand.

This special issue therefore offers new perspectives on the ways in which modernist studies, book history and translation studies can be brought into productive dialogue with each other. We are aware that this collection of essays can in no way address comprehensively the range of issues that it addresses. There is much more to be said, for example, about the translation of British modernist writing into non-European languages and cultures, and to understand the legacy of these 
works in translation particularly in the twenty-first century. Equally, there is an urgent need for traffic in the other direction to be explored, in order to understand better how modernist texts generated outside Europe and America were translated into Western idioms and cultures. Another area worth exploring is the role that publishers played in commissioning translations, and even writing translations themselves. The Russian-born Thomas Seltzer, an early editor of the Modern Library, translated a few books for the series (including Andreas Latzko's Men in War, an antimilitaristic novel which was banned in America during the First World War). In addition to his work as translator and editor, Seltzer owned his own publishing firm and issued twenty titles by D. H. Lawrence. The example of Seltzer highlights the cross-fertilisation of Anglophone modernism and texts in translations. Publishers also actively sought out new markets for difficult and experimental works in English. And yet, very few scholars have paid attention to the publishers' agents and booksellers that facilitated the diffusion of Anglophone modernism in Asia, South America and elsewhere. As Andrew Thacker rightly pointed out, 'of all the “institutions of modernism” that have been discussed since attention shifted from grace and beauty to the bottom line of modernism it is surely the modern bookshop that has received the least critical attention' ${ }^{24}$ This is particularly true of bookshops that sold modernism outside metropolitan centres in the West. We hope, therefore, that the essays in this special issue provide stimulating insights into the complexities of the transnational exchange of modernist ideas and texts, and develop further an exciting field of enquiry.

\footnotetext{
${ }^{1}$ Ezra Pound, 'Rabindranath Tagore’, Fortnightly Review, March 1913, pp. 571-79.

2 'Reviews for March: The Fortnightly’, Times of India, 19 March 1913, p. 9.

${ }^{3}$ Douglas Mao and Rebecca L. Walkowitz, 'The New Modernist Studies’, PMLA, 123.3 (2009), 737-48 (p. 738).

${ }^{4}$ Ann Ardis, 'Mediamorphosis: Print Culture and Transatlantic/Transnational Public Sphere(s)', Modernism/modernity, 19.3 (2012), v-vi (p. v).
} 
${ }^{5}$ Ardis, p. v.

${ }^{6}$ David Bradshaw and Laura Marcus, 'Introduction: Modernism as “a space that is filled with moving,”' in Moving Modernisms: Motion, Technology, and Modernity, ed. by David Bradshaw, Laura Marcus, and Rebecca Roach (Oxford: Oxford UP, 2016), pp. 1-8 (p. 1).

${ }^{7}$ Susan Stanford Friedman, 'Planetarity: Musing Modernist Studies', Modernism/modernity, 17.3 (2010), 471-99 (p. 474).

${ }^{8}$ Friedman, p. 475.

${ }^{9}$ Peter Brooker and Andrew Thacker, 'Introduction: Locating the Modern', in Geographies of Modernism: Literatures, Cultures, Spaces, ed. by Peter Brooker and Andrew Thacker (Abingdon: Routledge, 2005), pp. 1-5 (p. 3).

${ }^{10}$ Brooker and Thacker, 'Introduction: Locating the Modern’, p. 4.

${ }^{11}$ Andreas Huyssen, ‘Geographies of Modernism in a Globalizing World', in Geographies of Modernism, ed. by Brooker and Thacker, pp. 6-18 (p. 10).

${ }^{12}$ Amy L. Blair, 'Review of Modernism, Middlebrow and the Literary Canon, by Lise Jaillant', American Literary History Online Review, III, 2015, 1-4 (p. 2).

${ }^{13}$ Friedman, p. 489.

${ }^{14}$ Friedman, p. 490.

${ }^{15}$ Friedman, pp. 492-93.

${ }^{16}$ See Roland Végsö, ‘The Mother Tongues of Modernity: Modernism, Transnationalism, Translation’, Journal of Modern Literature, 33.2 (2010), 24-46.

${ }^{17}$ Rebecca Beasley, 'Modernism’s Translations’, in The Oxford Handbook of Global Modernisms, ed.by Mark Wollaeger and Matt Eatough (Oxford: Oxford University Press, 2012), pp. 551-70 (p. 551).

${ }^{18}$ Beasley, p. 554.

${ }^{19}$ Beasley, p. 552.

${ }^{20}$ Beasley, p. 552.

${ }^{21}$ Beasley, pp. 556, 559.

${ }^{22}$ Patrick Leigh Fermor, 'West Indian Days. Review of In the Castle of My Skin, by George Lamming', Sunday Times, 22 March 1953, p. 5.

${ }^{23}$ Arthur Calder-Marshall, 'Youth in Barbados’, Times Literary Supplement, 27 March 1953, p. 206.

${ }^{24}$ Andrew Thacker, ““A True Magic Chamber”: The Public Face of the Modernist Bookshop’, Modernist Cultures, 11 (2016), 429-51 (pp. 433-34). 